\title{
Local Discourse, Identity and the Search for a Filipino Philosophy: A Re-exploration through the Lens of Reynaldo lleto
}

Rhoderick John Abellanosa

\begin{abstract}
Working within the framework of Reynaldo lleto's postcolonial discourse, this paper re-explores the Filipino philosophy question and its contemporary relevance. Re-exploration in this context means re-reading and arguing for sustained discussions on Filipino philosophy. Divided into three parts, the paper presents the history and development of the Filipino philosophy debate and proceeds to an analysis and reflection on lleto's writing from Pasyon and Revolution to his more recent work. The third and final part proposes a rethinking of what has been identified as Filipino philosophy in the light of lleto's ideas. At the core of this endeavor is the contention that a culture-grounded philosophy is indispensable in nationhood and state-formation. Thus, whether it shall be called "philosophies in the Philippines" or "Filipino philosophy," or whatever possible nomenclature for such an endeavor, the most essential thing is that Filipinos consciously identify and shape their own discourse as a people. Finally, this paper argues for the relevance of continually discussing the question concerning Filipino philosophy.
\end{abstract}

KEY WORDS: Filipino philosophy, orientalism, Pasyon and Revolution, political philosophy, postcolonialism

Philosophy is important in the life of a nation. A people's reflections, critiques and analyses of themselves and their condition basically speak of the kind of persons that they are and the country that they have. Nationstate formation is incomplete if not accompanied by any philosophical discourse. The formation of a body-politic is not just about the creation of a system of institutions and the regulation of culture through legislation; it is also about a shared vision as well as a shared direction. Perhaps it is 
for this reason that, for several decades now, some academics have tried to articulate their views on a Filipino philosophy.

This paper re-explores the question of a Filipino philosophy, generally from a postcolonial viewpoint, and specifically through the lens of Reynaldo Ileto. While coincidence might not be scientific enough an explanation for this modest endeavor, nevertheless it is truly the "coincidence" of two events in 2012, one in the area of the Humanities and the other in the Social Sciences (i.e. history and Philippine studies), that fueled my desire to re-explore the question of Filipino philosophy in the light of Ileto's thought. Earlier this year, I came across a call for papers for an upcoming international conference, organized in tribute to Ileto's contributions to Philippine studies. ${ }^{1}$ The tribute was scheduled to coincide with Ileto's retirement from his professorship in Southeast Asian Studies at the National University of Singapore. As someone who has been formally trained in philosophy, it seemed to me that a glaring omission from the list of topics was Ileto's contribution to shaping local knowledge, i.e. Filipino philosophy.

On the topic of Filipino philosophy, the Philosophical Association of the Philippines also gave tribute to its pioneers through its Legacy Lectures which featured the ideas of the country's foremost philosophical minds: Emerita Quito, Roque Ferriols, Leonardo Mercado, Ramon Reyes, Romualdo Abulad, Zosimo Lee, Florentino Timbreza, and many others. ${ }^{2}$ The gathering of these Filipino philosophers has once again surfaced the question, "is there a Filipino philosophy?" This same question was asked and was attempted to be answered by Leonardo Mercado, Emerita Quito, Alfredo Co, and many others. While a cadre of professors academically trained in philosophy have invested talent and time to settle the problem, it nonetheless seems that many still doubt if such a genre of philosophy exists.

${ }^{1}$ The theme of the conference is "Historiography and Nation since Pasyon and Revolution (Philippines) Conference in Honor of Professor Reynaldo C. Ileto." It is organized jointly by Philippine Studies, Ateneo de Manila University; and Southeast Asian Studies, Center for Southeast Asian Studies, Kyoto University and will be held at the Ateneo de Manila on February 8-9, 2013.

${ }^{2}$ The 2012 Mid-year Conference of the Philosophical Association of the Philippines had the theme "Engaging Our Philosophical Pioneers," and was held last October 26-27 at the De La Salle University, Manila. 


\section{FRAMING THE DISCUSSION: A POSTCOLONIAL VIEW OF PHILOSOPHY}

What is being argued in this work is the relevance of continually discussing the question of Filipino philosophy. Whether it is called "philosophies in the Philippines," "Filipino philosophy," or whatever possible nomenclature, it is essential to note that we consciously identify and shape our own discourse as a people. From my perspective, there is no doubt that there is philosophical discourse among Filipinos. It is rather a matter of consciously articulating and figuring out this discourse. Thus "reexploration," in the context of this work, means re-reading and pushing for more discussion of Filipino philosophy, specifically through the lens of Reynaldo Ileto's work.

The choice of Ileto's work, as well as the relevance of his ideas to the discussion of Filipino philosophy, will be explained and justified in the succeeding presentation. While there is no intention to glorify Ileto's thoughts over other scholars, one must acknowledge his methodological contribution to Philippine discourse. In his work in Philippine studies, he has developed a kind of postcolonial approach to any study of the Filipino.

Based in this, it would seem helpful to revisit the idea of philosophy as a discourse in the light of postcolonialism. Despite the many works on the subject matter, I still find it most helpful to return to Edward Said's landmark work, Orientalism:

In any society not totalitarian, then, certain cultural forms predominate over others, just as certain ideas are more influential than others; the form of this cultural leadership is what Gramsci had identified as hegemony, an indispensable concept for any understanding of cultural life in the industrial West. (7)

Said's words essentially capture the guiding spirit of postcolonial discourse, i.e. the struggle of peoples subjected to imperialism and colonization to think and write of and for their selves. It is a resistance against the "positional superiority, which puts the Westerner in a whole series of possible relationships with the Orient without ever losing the relative upper hand" (Said 7). It is imperative to frame the succeeding discussion in light of Said, due to the still-pervasive bias that philosophy is a Western enterprise. As such, it is viewed by most students and teachers of philosophy as a discourse that has something to do with "isms" of the West, i.e. Aristotelianism, Scholasticism, Pragmatism, etc. My experience while on a graduate fellowship in Singapore is a good example. Over lunch, a 
Senior Research Fellow from my host institution asked, "What is your research about?" I answered: "The development of Filipino philosophy?" The fellow responded, "What? What does your culture have to do with Frege or Hume?" His attitude is reflective of the attitude of some scholarsWesterners and Filipinos alike-who still find it unthinkable to talk about Filipino philosophy.

What Said called the "West's upper hand" has been deeply ingrained in the consciousness of many. Thus it is difficult for many to appreciate that philosophy flows from people's reflections on and explanations of their world, a capacity that all individuals are bestowed with. Those who continue to define philosophy as a discourse and discipline that "linearly" comes from Europe and North America are blinded, either by accident or intention, to the deeply intertwined connection between the production of truth and the power that produced it, i.e. "Western philosophy" and the "imperialisms that brought it to the Philippines." Here we are reminded of some words from Enrique Dussel:

Modern political philosophy originated in reflections on the problem of opening the European world to the Atlantic; in other words, it was a Spanish philosophy. As such it is neither Machiavelli nor Hobbes who initiates Modern political philosophy, but those thinkers who undertook the expansion of Europe toward a colonial world. (3)

Thus, working within the framework of the relevance of postcolonial discourse and its relevance to Filipino philosophy, the succeeding discussion shall presented in three strokes: (1.) the history and development of the Filipino philosophy debate; (2.) an analysis cum reflection of Ileto's writing from the Pasyon and Revolution up to the most recent writings; and (3.) a re-exploration of the Filipino philosophy question in the light of Ileto's thought.

\section{REVISITING THE FILIPINO PHILOSOPHY QUESTION}

A brief overview of Filipino philosophy is needed at this junction to situate the relevance of Ileto's thoughts. I thus consider the importance of guiding the reader as we navigate the rough seas of Filipino intellectual history (it is vast and at times figuratively stormy, often reflective of the society it represents). 


\section{Filipino Philosophy: the Beginnings}

Filipino philosophy as an academic issue or question clearly emerged at the height of calls for nationalism in the 1960s (Filipino Philosophy, Traditional Approach 1), when nationalism was felt most strongly in the area of education. While it may be true that the generic sense of the term 'nationalism' has existed since the birth of the republic, nevertheless the Filipinization of formal education did not immediately follow the nominal christening of the nation-state. Philippine education after the Spanish regime remained colonial, thus philosophy as an academic discipline did not immediately metamorphose despite the 1898 Revolution. One can even say that the formal philosophy taught in schools remained immune from, if not resistant to, nationalist developments. An example of this would be the University of Santo Tomas, which remained scholastic and Thomistic in orientation even up to the 1980s, and partly up to this point in time. The University of the Philippines, unsurprisingly, followed the lead of the analytic tradition prevalent in the United States, under whose colonial administration the university was established.

Quito has observed that some Filipino academics in philosophy felt that there was a need to ask whether there was a Filipino philosophy at a time when the country was at a crossroads of nationhood (40-43). The beginnings of Filipino philosophy therefore must be understood within the context of the struggle, not just for political recognition, but more importantly to establish a distinct identification of the Filipino people, capable of reflecting about the world and the events around them.

In her book, The State of Philosophy in the Philippines, Quito identified two levels of understanding of philosophy: the academic and the grassroots (6). While she acknowledged the existence of the second level or type of philosophy, her focus was on the first type. She asserted that the Philippines does not have a monolithic philosophical orientation and that one should look into the universities offering philosophy programs in order to know these different orientations (10).

The efforts to Filipinize the discourse of the discipline are indicative of the nationalist factors which led to the shaping of Filipino philosophy. For example, the Jesuit Roque Ferriols started to teach philosophy in Filipino in Ateneo de Manila University, and translated a part of Plato's Symposium to Filipino (Ensayklopidiya 190). He also wrote the books Pilosopiya ng Relihiyon, Pambungad sa Metapisika and Mga Sinaunang Griyego.

De La Salle University (DLSU) was home to a number of academics who tried to make philosophy available and understandable in Tagalog. There, in 1993, Emerita Quito, Romualdo Abulad, Florentino Timbreza, and Herminia Reyes compiled the Ensayklopidiya ng Pilosopiya which still 
stands as the most comprehensive Filipino work in academic and professional philosophy. A product of the four authors' collaborative efforts, the work provides encyclopedic descriptions of common or key philosophical terms, arranged from A to Z. In 1990, the Department of Philosophy of DLSU published the compilation Readings in Filipino Philosophy. It contains essays from Leonardo Mercado, Ramon Reyes, Florentino Timbreza, and Romualdo Abulad, among others, the overarching theme of which is the search for a Filipino philosophy.

But perhaps there is no scholar in the discipline whose argument for a Filipino philosophy is as developed as Leonardo Mercado who, in 1974, wrote what is now considered a landmark in Filipino philosophy: Elements of Filipino Philosophy. Undoubtedly, many scholars did not agree with Mercado, but as it turned out (and as has been common in intellectual history) the controversy over his work became fertile ground, leading to the growth of more discussions on the topic (Co 10-12). Other works by Mercado worth noting are Applied Filipino Philosophy and Elements of Filipino Ethics.

At around the same time, individual works on a variety of topics already signaled a national spirit, oriented towards making philosophy relevant to the lives of the people and their country. Worth mentioning are the works of Emerita Quito, Pilosopiya sa Diwang Pilipino, Timbreza's Pilosopiyang Pilipino, and Abulad's Diwa at Kaisipan ng Pilipino sa Kasaysayan ng Himagsikan. Also relevant are Quito's The State of Philosophy in the Philippines, Abulad's Options for a Filipino Philosophy and The Filipino as a Philosopher in Search of Originality. Timbreza also wrote in English on the subject matter, Filipino Philosophy: Understanding Filipino Philosophy and Filipino Logic: A Preliminary Analysis.

Another approach that emerged as a response to the question of a Filipino philosophy was the application of non-Filipino philosophy or western thought to the milieu or lived-experience of the Filipino. Examples of this are Abulad's books, Si Kant at ang Pilosopiya sa Pilipinas, Kant and the Task of Contemporary Philosophy, and Kant for Filipinos. Florentino Timbreza's Ang Landas ng Buhay ayon kay Lao Tzu is another example of this.

According to the DLSU Department of Philosophy, three synthetic approaches to Filipino philosophy were initially identified by most proponents of the movement: (1.) anthropological, (2.) historical, and (3.) progressive (68-78), and the limitations of each approach were identified. These limitations, however, paved the way for other scholars to further the discussion on Filipino philosophy. 


\section{Filipino Philosophy: Expanded}

Rolando Gripaldo classified the approaches in Filipino philosophy as follows: (1.) anthropological, (2.) traditional, and (3.) constitutional. His bias, however, is for the traditional approach, which he describes as studying the "individual activity of philosophizing" (Traditional Approach 4). Coming from an orientation that privileges individual perspectives rather than communal or collective worldviews, he identified publications or works that would comprise the gestalt of Filipino thought. Many of these are works classifiable as political and social philosophy, and philosophy of history.

Like Gripaldo, F.P.A. Demeterio offers what may be called a criticalsynthetic approach to Filipino philosophy, which means he prefers to problematize the matter as a discursive whole rather than as bits and pieces of individual enterprises. Two of his essays (available on the web), "Re-reading Emerita Quito's Thought Concerning the Underdevelopment of Filipino Philosophy," and "Thought and Socio-politics: an Account of the Late Twentieth Century Filipino Philosophy," are must-reads, outlining his fundamental contentions on the matter.

In "Thought and Socio-politics," this emerging Filipinologist argues that the search for Filipino political philosophy is the nation's continual project. Moreover, he asserts that three points must characterize Filipino political philosophy as an integrated thought. First, it "must be a reflection and questioning on and of the Philippine reality creatively using any philosophical, cultural, or sociological paradigms." Second, it must be a "Filipino's search for answers creatively using again any philosophical, cultural, or sociological paradigms." Third, "whatever its output may be, it must go back to tradition that will supply the future philosophical endeavors with paradigms and methodologies."

Demeterio's expected characteristics of Filipino philosophy would make more sense if read in light of his interpretation of the general direction of contemporary philosophizing in the Philippines. He believes that the crises experienced by the country has traumatized the people's way of thinking, thus,

If we look at Filipino philosophy today, what we can notice easily is its characteristic shirking away from the political, the social, the historical, and the economic. It has become a philosophy that is dispassionate, cold, and devoid of libido; a philosophy that is lulled by some plenitude of innocuous things, such as the lofty tenets of scholasticism and humanism, 
the endless mazes of language and logical reasoning, and the exoticism of oriental thought. ("Thought and Socio-politics")

What has been discussed so far is that kind of Filipino philosophy that belongs to the academic classification, those who are strictly trained in philosophy. However, there are academics in the Philippines, though not trained in philosophy (but in other disciplines such as the social sciences), whose works are philosophical and have a strong flavor of philosophical discourse. Their works and contributions cannot just be disregarded. On this note, the discussion is brought to another generation and group of scholars whose views on Filipino philosophy are different, yet inseparable, from this discussion. Here we can name a few of these scholars: Zeus Salazar, Remigio Agpalo, Cesar Majul, Vicente Rafael, E. San Juan Jr., and Resil Mojares among many others. Rolando Gripaldo, in Filipino Philosophy: A Critical Bibliography, 1774-1997 lists more than 5,500 entries of works by Filipino scholars coming from different disciplines, including politics, which may be considered contributions to the shaping of Filipino philosophy.

\section{CONTESTING FILIPINO PHILOSOPHY}

The effort to figure out a Filipino philosophy is not without contestation. When nationalism was sidelined by neocolonialism, the effort to clarify whether or not there is a Filipino philosophy waned. Moreover, when neocolonialism reached its height in globalism, Filipino philosophy became an almost irrelevant topic. The question as to whether a Filipino philosophy exists in a rapidly growing, cosmopolitan world became serious. Those into formal philosophy have become more concerned with benchmarking against international standards. The Filipino philosophy question seems to have become a thing of the past, or maybe even a hangover from the years of the nationalist struggle.

Some of the serious critics of Filipino philosophy are Filipino scholars themselves who, in their individual ways, critique the quest for an indigenous Filipino thought. One main argument is that the term "Filipino" is itself problematic. Who is the Filipino or what is a Filipino? There seems to be a strong puritan tendency on the part of these people not to believe that there is a Filipino philosophy, not until the term Filipino becomes clear, without any analogousness in meaning. One good example of this position is that of Alfredo Co who said: 
I have a profound respect for the hard work undertaken by my colleagues in philosophy, but I definitely disagree with what they refer to as Filipino philosophy. After over twenty years of comparing Bisaya, Ilokano, Bicolano, Tagalog and Ilonggo, Leonardo N. Mercado, SVD is still on the same level of comparing them but he has not established what can be categorically claimed as "the" Filipino philosophy. ("Doing Philosophy in the Philippines" 41)

But Co's argument against a Filipino philosophy is not unproblematic. His critique is directed against Leonardo Mercado, whose method is basically anthropological and whose goal is the search for the essential Filipino. Co's claim that there is no Filipino philosophy ala Mercado's desired construct is as inconclusive as Mercado's. Mercado did not begin with the fact that the Philippines has existed as a state, and, all the verbal gymnastics notwithstanding, territoriality has helped shape and define the history and culture of those who call themselves Filipinos.

It can therefore be argued that a Filipino philosophy need not be that which comes from the culture of "the essential Filipino," but rather that which is born out of the attempt to shape and clarify the nationhood and statehood of the Filipino people. Co's objection to a Filipino philosophy is actually an objection to Mercado's interpretation, not necessarily a conclusion that there is no Filipino philosophy.

Co tried to salvage Filipino philosophy by suggesting that one need not understand the matter by looking for the essential Filipino. One can understand from this that, if ever there is a Filipino philosophy, it is simply "doing philosophy" by Filipinos. To quote him directly:

Those of us who are still toiling in a desperate search for the Filipino soul and the Filipino philosophy are really lagging behind. Many of our Filipino thinkers have already done their part by philosophizing and writing. In the process, they have become philosophers. And because these are Filipinos philosophizing, then we call the body of their works Filipino philosophy. For when the Filipino philosophizes, he at once claims the right to claiming his own views. ("Doing Philosophy in the Philippines" 62)

Co's position seems to be very circuitous. He concludes that there is a Filipino philosophy while arguing that those "searching for the Filipino soul and the Filipino philosophy" have lagged behind. While his position that "doing philosophy" among Filipino scholars would eventually contribute to an understanding of "philosophizing in the Philippines," the position that questions if there is a Filipino philosophy, for me, remains 
objectionable. Just because we cannot arrive at a pre-lapsarian idea of an essential and universal Filipino due to cultural variances does not mean that the effort to continually philosophize on who we are, and what we may become, has become irrelevant or pointless.

Like Co, Romualdo Abulad asked the question "Is Filipino philosophy still relevant?" But instead of answering the question, he concluded by saying that the question "is missing the point." In a paper entitled "Pilosopiyang Pinoy: Uso pa Ba?", Abulad surveyed the representative Filipino scholars who attempted to define and figure out Filipino philosophy. Abulad ended up critiquing the anthropological and phenomenological approaches of Leonardo Mercado, Albert Alejo, Florentino Timbreza, Rolando Gripaldo, and Dionisio Miranda. In the end, he pointed out (similar to Co) that Filipino philosophy is all that comes from the efforts of Filipinos who philosophize. In his own words: "gather all the writings I have just mentioned above, see for yourself how much work has already been done, quantitatively, and then assess the intellectual worth of its entirety, qualitatively" ("Pilosopiyang Pinoy"). But precisely, the same immense data makes the question about Filipino philosophy relevant. So, why say that the question is missing the point?

Both Co and Abulad, in analyzing the question concerning Filipino philosophy, seem to have focused their concern exclusively on "philosophy" and not the "Philippines" and "Filipino." In the case of Co, he seems to suggest that it is pointless to search for the essential Filipino, as there could be none such thing. However, to reiterate the thesis of this work, the search for a Filipino philosophy is not irrelevant and insignificant.

In recent years, the question of Filipino philosophy, given the same interlocutors, seems to have reached an impasse. Perhaps not until the Legacy Lectures of the Philosophical Association of the Philippines was there a serious revival of the question. Really, is there a Filipino philosophy? At his lecture, Abulad said:

I have always taken the stand that what we call Filipino philosophy is nothing but the collection of writings of our Filipino philosophers, and in that definition I exclude no one. If this crop of philosophers whom you now call pioneers have contributed anything to the development of philosophy in our country, it is not so much because we have been and perhaps still are your teachers and friends as because we are leaving you with quite a corpus of writings, never mind if you will agree or disagree with us. (6)

Taking cue from Abulad, the Filipino philosophy question once again becomes relevant. What is important is that we shift the focus away from 
the "search for the essential Filipino," and instead focus on the fact that we are Filipinos; this is given. Being Filipino is our "facticity," to use Heidegger's term. Moreover, the discussion of Filipino philosophy does not come from an established definition of ourselves. Rather, the discussion originates from the awareness that philosophy can help us better understand our being Filipino and our being a nation. Thus, all the efforts to figure out a Filipino philosophy remain important because philosophizing enables us to come to terms with ourselves. This idea of coming to terms with ourselves brings us to the contribution of Reynaldo Ileto to the question of Filipino philosophy.

\section{RELEVANCE AND RE-THINKING}

Whether Ileto has a place in Filipino philosophy is a matter than can be settled if we move out of the limited idea that philosophy is a profession like Law or Medicine, composed of licensed individuals endowed the privilege of practice by an institution. If we think of philosophy as a profession, then this whole exploration should end here. This, however, is not the case. As Maurice Merleau-Ponty asserted, "Philosophy's center is everywhere and its circumference nowhere.... Philosophy is everywhere, even in the 'facts', and it nowhere has a private realm which shelters it from life's contagion" (qtd. in Park 7). This does not mean, of course, that we remove all the criteria that determines what is or is not philosophical. Certainly, cheap talk or mere sophisticated words cannot be considered philosophical outright.

What accounts for philosophical thinking is the sustained, systematic drive towards reflexive thought, and correlation of such reflection to a broader discourse on the fundamental questions of human existence. Unlike science, which is objective and guided by universal laws of nature, philosophy is subjective. Although philosophy subscribes to certain methods, nonetheless, each method is conditioned by the milieu in which it developed. Thus, there are philosophical ideas that have been contributions of persons not formally identified as scholars of philosophy. Though formal training and professional engagement in philosophy may establish a person's credentials, we cannot deny that genuine and systematic reflections on certain aspects of human existence can come from those trained in disciplines other than philosophy, such as history, sociology, etc.

Although Ileto is best known for his expertise in Southeast Asian Studies, particularly Philippine history and culture, philosophy was part of his undergraduate studies as a Humanities student at Ateneo de Ma- 
nila University. In his recent essay "Scholarship, Society and Politics in Three Worlds," he narrated his seminal training in the works of Sartre, Buber, Husserl, Merleau-Ponty, Heidegger, Weber, and Aquinas (107). As a scholar, Ileto established his niche in the areas of history and anthropology, and later in interdisciplinary studies on religion and politics. His best known work is Pasyon and Revolution: Popular Movements in the Philippines, 1840-1910.

In the course of the succeeding discussion we shall try to discover insights from Ileto's work that help us re-explore the question concerning Filipino philosophy. In order to do this, we shall first conduct a survey of his works and analyze to see if there is an overarching theme, and inquire whether such a theme is philosophical. Secondly, it would be helpful to trace the context of this overarching theme within the continuum of Ileto's scholarship.

\section{AN INVITATION TO RETHINK DISCOURSE: FROM PASYON TO ORIENTALISM}

A survey of Ileto's writings is necessary in order to identify the philosophical theme/s of his ideas, and eventually figure out his possible contribution to Filipino philosophy. I take the liberty of dividing his scholarship into two distinct yet inseparable segments (although this is not to suggest that there was an Early and a Late Ileto). The importance of this categorization is simply to aid the thematic analysis of his scholarship. I propose to look into Ileto's works through the lenses of two themes: the Ileto of the Pasyon and the Ileto of the Orientalism debates. ${ }^{3}$

\section{Pasyon and Revolution}

Pasyon and Revolution is not just about the Pasyon or the Revolution. Ileto himself said it "goes beyond the subject of the masses and their participation in the revolution" (Pasyon and Revolution 8). This line already anticipates the common critique that the book does not say anything

${ }^{3}$ My classification of Ileto's works into two stages, Pasyon and Orientalism, was something I showed to Ileto himself in the course of my research in Singapore from May-July 2011. Ileto's response was: he has not read of anyone who approached or studied the corpus of his writings the way it is done in this essay. In fact it is on the basis of Ileto's remarks that I got the inspiration to pursue this essay's publication. (Through the Graduate Research Fellowship of the Asia Research Institute of NUS, I had the chance to personally interview Ileto thrice; Dr. Julius Bautista of the SE Asian Studies Department of NUS was my mentor.) 
new (one critique, for example, is that Renato Constantino already did a reading of the Philippine revolution, and of Philippine history, from the margins).

Using five events in Philippine history, Ileto meticulously analyzes how movements arising from specific discourses-not necessarily the formally accepted ilustrado revolutionary discourse-have been forgotten or, worse, marginalized by the standard reading of Philippine history and the 1898 Revolution. To highlight his point, Ileto begins his narrative with the Lapiang Malaya and their tragic end in 1967. Considered by observers as a cult or a millenarian sect, the members of the Lapiang Malaya clashed with the government's soldiers outside the gates of Malacañang. One can vividly imagine the tragedy-a group of men armed with "sacred bolos" (machetes), "anting-anting" (amulets), and "bullet-defying uniforms," facing state troops armed with their automatic weapons (Pasyon and Revolution 1).

For many, the encounter was another not-so-relevant event in history, no different from any other common street tragedy. As Ileto put it, "When the smoke from the encounter had cleared, only a few, if any, of the country's politicians and avid newspaper readers really understood what happened" (1). Could there be a better point of departure for a work analyzing the value of decentralized discourses and voices from below than a discussion of a group that has been marginalized in mainstream social history?

For Ileto, the tragic fate of the Lapiang Malaya is a cry for attention from scholars, particularly those who study social movements and sects in the Philippines, to seriously revisit their preconceived anatomies of resistances and revolutions in the country. The Lapian was not without a cause; its goals were "true justice, true equality, and true freedom for the country" (1). Driving home his point, he writes, "Anyone familiar with Philippine history will recognize the Lapiang Malaya's continuity with the Katipunan secret society of 1896" (3).

The average reader with a mainstream understanding of Philippine history would surely find Ileto's observation very unfamiliar. For one, students have been told in their Philippine history classes that the Katipunan was a group of ideologically-driven individuals whose goals were to liberate the country from the oppression of the Spaniards, particularly the friars. Students are further told that it was a group of nationalistic individuals whose struggle for sovereignty served as the foundation of what is now known as the Philippine state. From this kind of orientation, one can understand why it would be difficult for the average reader to connect the Lapian to the Katipunan. Moreover, the same reader has been made to understand that the Katipunan was not composed of fanatics whose lives 
were wasted all for a silly cause. Simply put, the common image of the Katipunan is essentially different from that of the Lapiang Malaya.

Elitist views of the Katipunan created a well-defined image of the group, which has been given to the public time and again. In Ileto's own words, "our difficulty in understanding the Lapiang Malaya can be stretched backward in time: do we really understand what the Katipunan uprising was all about?" (3) Further stressing the point, Ileto uses Revolt of the Masses (a classic book of the respected Filipino historian Teodoro Agoncillo) as an example of the sweeping characteristic of historical reconstructions that relegate to the periphery, if not forget completely, the discourses and stories of certain groups and people who participated in major events in Philippine history. Here, we quote Ileto at length in order to do justice to his point. He writes:
Although I found the story of the Katipunan and its supremo, Bonifacio, vividly constructed by Agoncillo, I remained intrigued by the relation- ship of the title of the book to its body. The physical involvement of the masses in the revolution is pretty clear, but how did they actually perceive, in terms of their own experience, the ideas of nationalism and revolution brought from the West by the ilustrados? Agoncillo assumes that to all those who engaged in revolution, the meaning of independence was the same: the separation from Spain and the building of a sovereign Filipino nation. (Pasyon and Revolution 4)

This critique of Agoncillo's brand of historiography is about more than the search for more facts that can be added to a linear narrative of history. It is an interrogation of a specific view and reading of events from available documents about the Philippines and its people; how they are presented as neatly-connected or interwoven stories-with characters in well-defined roles, neatly situated in a mentally-constructed social arrangement. This point of criticism recurs in the other chapters of Pasyon and Revolution, in reference to different parts or events in the Philippine history. For instance, in Chapter Three, "Tradition and Revolt," Ileto cites how Stutervant, another scholar of Philippine studies, "ignores" the so-called colorum society in his study of revolutions in the Philippines, "perhaps because it blurs the distinction he makes between the revolution (a 'Great Tradition' phenomenon) and messianic movements (a 'Little Tradition' phenomenon)" (77-78).

Ileto's discussion of how various movements are repeatedly marginalized in mainstream Philippine historiography brings to mind Lyotard's concept of the "metanarrative." The repeated marginalization seems to be 
characteristic of the designed and created narratives of Filipino struggle, revolution, and emancipation. These metanarratives are what Ileto would like to subject to suspicion, if not deconstruction. What he writes in another work, Filipinos and Their Revolution, is illuminating in this regard: "What the study of Philippine politics often misses are the readings of the play by the various sections of the audience" (166). Ileto sees that the need to challenge the dominant narrative is valuable, because discourses from below have been continually suppressed by the elite or the ilustrado. Yet, every now and then, these suppressed or forgotten voices, or what we may call micro-narratives, surface in order to contest those enthroned at the center. To rephrase what Ileto says in Pasyon and Revolution, "the majority of those who fought in the revolution" cannot just be "regarded as essentially passive beings suddenly mobilized into action by 'blind obedience' to patrons or supernatural forces" (80).

The depiction of the masses as blindly obedient does not do justice to their struggle and their cause. While those in power may not care for the voices of the periphery, the continual persistence of the struggle for recognition would eventually erupt in some other form. Not to mention the fact that, in the Philippines, the enframing and marginalization of the masses has been used as an effective instrument by those in power to limit the masses' further emancipation. Ileto presents us with a clear articulation of this phenomenon in Pasyon and Revolution:

The issues that this book is concerned with go beyond the subject of the masses and their participation in the revolution. All around us we hear of the need to define the Filipino personality, style of politics, and social system. Yet the masses are hardly encouraged to participate in this effort. They make their statements in idealized portraits of rural life or, to take the other extreme, socialist representations of clenchfisted peasants. (8-9; cf. 78-79)

Aside from presenting an alternative historiography of the revolution, Ileto also raised an important question concerning the methods of understanding history, social change, and politics. In his essay "Outlines of a Nonlinear Emplotment of Philippine History," he criticizes linear history as "a weapon in the struggle for and against domination of all shades" (126).

To substantiate his analysis of Philippine discourses "from below," Ileto used documents and sources from the marginalized masses, such as poems, songs, scattered autobiographies, confessions, prayers and folk writings ("Outlines of a Nonlinear Emplotment" 10). An example of this is the Pasyon Pilapil, which, according to Ileto, "was not simply, sung, heard, 
or celebrated by the masses in the nineteenth century. It was lived, both individually and socially, during the Holy Week and oftentimes beyond it" (22). Moreover, Ileto believes, resorting to sources from below does not necessarily mean rejecting or disregarding the other texts of history (in another essay, he referred to sources from below as parts of the Little Tradition as distinguished from the Great Tradition). As he writes in a reply to a critic, "[t]he point is instead of relying on 'common sense' criteria or reified notions of nationalism and revolution, we must first establish actual units of meaning through textual analysis" ("Critical Issues" 103-04).

Ileto's Pasyon and Revolution is a critique and a contribution interrogating the established views of Philippine history and historiography. As will be further discussed below, the book was hotly debated, which led him to further elaborate his ideas in later writings. His subsequent works such as Critical Questions on Nationalism, "Outlines of a Nonlinear Emplotment of Philippine History" and, most notably, Filipinos and Their Revolution, are must-reads for gaining a better understanding of what I have called the Ileto of the Pasyon.

Little did many know that what Ileto started in Pasyon and Revolution was not just a question of historiography. It was also to be a discourse on method, which, a decade or so later, would have bearing on the reinterpretation of Philippine studies and Filipino thought. Ileto's interest in the Philippines did not end with the Pasyon; rather, the Pasyon led him to delve into the intricacies of local culture, religion and politics. It eventually led him to seriously examine pervading and emerging discourses of Filipinos, and how these discourses were not neutral, but instead determined by the economic and political interests of those who made them. At this point of his scholarship, Ileto goes beyond the business of history. Here, we enter into what I have called the "Ileto of the Orientalism debates," referring to his debates with Carl Lande, John Sidel, and other scholars in the field of Philippine and Southeast Asian studies.

\section{Orientalism Debate}

Some twenty years after Pasyon and Revolution was first published, Ileto was involved in another controversy, this time on Orientalism, the origins of which can be traced to a debate between him and Glen May on Andres Bonifacio. Three of Ileto's essays, published as a monograph entitled Knowing America's Colony: A Hundred Years from the Philippine War, served as the starting point of the issue. The third essay in particular, "Orientalism and the Study of Philippine Politics," later re-published in the Philippine 
Political Science Journal, attracted responses from Ileto's critics (Lande, Sidel, and others) whose articles are found in the 2002 issue of the same journal. Ileto's essay on Orientalism also attracted reactions from nonAmerican scholars such as Arnold Azurin and Antonio Contreras.

The first few lines of "Orientalism and the Study of Philippine Politics" set the tone and direction of the rest of the debate. In it, Ileto charged Western scholars of being biased in their scholarship and that "colonial knowledge was caught up in ideas of evolutionary development, racial difference, and superiority of 'the West' vis-a-vis 'the East'" (Knowing America's Colony 41). The essay highlighted what may be called the lopsided presentations of Filipinos in Stanley Karnow's In Our Image. The discussion, however, was more than just about the Pulitzer Prize-winning journalist's comments about the Philippines. Ileto went on to trace the underpinnings of, and influences on, Karnow's depictions. In the process, Ileto brought up scholars whom he alleged had an Orientalist bias, i.e. essentialized the Philippines, including Glenn May (46).

For those familiar with the May-Ileto debate on Bonifacio, it is noticeable that Ileto's critique of Orientalism echoed his criticism of May's depiction of Bonifacio (Filipinos and their Revolution 218). He calls May's interpretations "revisionist" (Knowing America's Colony 49) and accuses him of "feeding into Karnow's" Orientalist readings of Philippine politics. After discussing May, Ileto goes on to mention the scholars Alfred McCoy, Carl Lande, Michael Cullinane, and John Sidel, paiting them in the same light. One exception was Resil Mojares, whom Ileto described as "point[ing] towards alternatives to the Orientalist construction of Philippine politics" (62).

Ileto's monograph may at first be seen as another Filipino historian's critique of western scholarship. However, this was not the case. Not only did Ileto question his opponent's interpretations of the facts, he called into question the very analytical framework of their interpretation of Philippine history, i.e. an "essentialized" notion of Filipinos in addition to "Orientalist" and "colonial" biases. It is Ileto's conviction that these analytical frameworks are the reason why images of the Philippines like Karnow's abound. As he puts it,

Ultimately, the question I ask is whether elements of colonial discourse continue to inhabit, in suitably amended and updated terms, recent writing on Philippine politics. Mesmerized by the trappings of modern scholarship, have we failed to interrogate the conditions for positing what is "true" and "essential" about Filipino political behavior. (41) 
Responding to Sidel's accusation of anti-American bias, Ileto dismisses it as a "facile judgment" ("On Sidel's Response" 152-54). Citing his other work, Ileto argues that he has previously subjected Filipino writers and scholars (such as Teodoro Agoncillo, Renato Constantino, Ferdinand Marcos, and Amado Guerrero [Jose Maria Sison]) to the same criticism (153). Ileto's claim in the Orientalist debate has nothing to do with antiAmerican sentiment, or with a belief that the Philippines should not be judged by Americans. Neither is it about the absence of local political pathologies. Rather, Ileto asserts that there is a clear need to subject Philippine politics to criticism but this criticism must be "on its own terms" (Knowing America's Colony 64).

Three years after Ileto's response to Sidel, the article "Philippine Wars and the Politics of Memory" was published. The essay combined the seminal framework of Pasyon and Revolution with a heuristic analysis of the Philippines' support for America's war in Iraq. In the essay, Ileto weaves a narrative that combines a critique of America's "invasion of Iraq" with a remembering of the Philippines' experience of wars and invasions under the United States. Analyzing Filipinos' support for US invasion of Iraq, Ileto engages in, as the title puts it, "the politics of memory."

He calls the US invasion of Iraq a kind of déjà vu, eerily reminiscent of Philippine history, especially that of American military intervention. Revisiting Philippine history, one finds that the United States played a major role in four of the country's wars: in 1896 against the Spaniards, in the 1899 Filipino-American war, in the Second World War from 1942-45, and in 1947 against the Huks, a rebellious peasant army in Luzon that was communist in ideology ("Philippine Wars" 217-18). Then-US President George W. Bush even referred to three of these wars in a speech before the Philippine Congress in order to remind Filipinos of the irreplaceable part America played in the Filipino people's "great story" (215).

But what is Ileto driving at in this analysis? The essay shows the progression of the study of Philippine politics-a study that was first mainly concerned with political history, later on evolving to engagement with political science, and finally in its most recent phase, studies Philippine politics within the context of history. This mode of studying Philippine politics does not engage history as pure history, but as something also shaped, conditioned, and sanitized by politics. This reminds me of what Lemert and Gillan wrote of Foucault's social theory:

History, philosophy and politics are historically active strata which divide and separate to form a three-dimensional volume. The subterranean cavern thus created is an open historical space in which power and knowl- 
Asian Perspectives in the Arts and Humanities 3.1 (2013): 35-59

edge are dispersed, resonating with each other and the three enclosing strata which, in turn, shift over time in relation to each other. (59)

What is apparently consistent and central in Ileto's thought right from Pasyon and Revolution up to the Orientalism debate is the attempt to allow histories from below and marginal discourses to come to the fore. His post-structuralism is evident his antagonism of "linear history," "essentialist readings," and "Orientalism," among others-all of which are part of the 'grand design' of structural and functionalist traditions in the social sciences. The valorization of discourses outside the center and from below is Ileto's trademark. He also differs from other scholars who subscribe to a similar view because he has brought it into the praxis of writing history, as evidenced by Pasyon and Revolution. By questioning things that are, for many historians, "given," if not "integral," to the study of history, Ileto has moved from the domain of history to that of philosophy. As Ileto himself asserts in Critical Questions on Nationalism: A Historian's View:

From the moment the typical student begins to learn about himself, his society, history and culture in books, the mass-media and the classroom, he becomes immersed in ideas of development, emergence, linear time, scientific reason, humane pragmatism, governmental ordering, nation building, etc. He becomes so immersed in them that he takes them to be universal categories, part of the natural ordering of things. Little does he know-for rarely do his teachers tell him-that such categories are historical, that they were devised at a certain time in the past by men bound by their unique interests and environments. [emphasis added] (3-4)

Ileto's thought, characterized by post-colonial and post-structural discourse, is explicit in his work after Pasyon and Revolution. While one can discern Foucauldian themes and anti-positivistic undertones in that book, nevertheless these are clearer and demonstrable in the later writings. Some examples of these are the following works: "Critical Issues in 'Understanding Philippine Revolutionary Mentality" (in which he responds to Milagros C. Guerrero's criticism), the abovementioned "Outline of a Nonlinear Emplotment," the three essays in Knowing America's Colony, and "On Sidel's Response and Bossism in the Philippines." Some commentators have also made the same observations on Ileto's approach (namely Contreras, Lande, and Sidel). These post-structural and post-colonial themes show us Ileto's philosophical bent-an orientation that shall be discussed further below. 


\section{PHILOSOPHICAL UNDERPINNINGS OF DEBATES ON METHOD}

Some of the abovementioned critical essays aimed against Ileto focus their attention on Ileto's methods and analytical framework. For instance, in her critical and biting book review of Pasyon and Revolution, Milagros C. Guerrero advised Ileto to be more objective by using the "canons of historical methodology." Guerrero argues that by using "poems, songs, and even 'dreams'," not to mention some hermeneutic issues, Ileto's reconstruction-particularly of the hero Andres Bonifacio-borders on creative fiction (240). In pursuing her critique, Guerrero did not hesitate to point out Ileto's "faults" which "required cautious attention" (256). Her degree of disagreement with Ileto's method is made even clearer in the following:

The methodology of the study, particularly the technically controversial procedure of drawing history from literature, will unquestionably generate much discussion and disagreement among Philippine historians ... It is hoped that some of the younger Philippine historians will soon accept the challenges-and the perils-of producing the research and the arguments that will refute or strengthen the author's thesis. (256)

In another instance, Carl Lande calls out Ileto for employing Critical Theory, which Lande calls a "parlor game." Lande denigrates Critical Theory, Ileto's preferred analytical framework, claiming that it "thrives mainly in university language departments, which are not known for their expertise in history and politics." Lande further asserts that at his university, the faculties of History, Political Science, and Philosophy, "do not take Critical Theory seriously" (126).

Guerrero's and Lande's criticisms concern philosophical issues which include (though not limited to) questions concerning objectivity, ideology, and the politics of truth. These debates on method between Ileto and other scholars further reveals the philosophical underpinnings of Ileto's perspective on politics and social change in the landscape of Philippine history. This helps us understand further the frame within which Ileto advances his scholarship, i.e. a critique of Philippine historiography and social science that has been rooted in western positivism.

Even more revealing is a passing comment Ileto makes in the Acknowledgments to the 1979 edition of Pasyon and Revolution, where he mentions his distrust of behaviorism in the social sciences. This underlying philosophical orientation against positivism and behaviorism is made even more explicit in his most recent publication, "Scholarship, Society, and 
Politics in Three Worlds." In it, he recalls and acknowledges the personal and professional influence of James Siegel and Benedict Anderson. Siegel and Anderson were professors at Cornell University, where Ileto did his $\mathrm{PhD}$ research, which would eventually become Pasyon and Revolution. Their influence on Ileto is worth noting, as both scholars were not positivist in their approach. In a personal interview, Ileto recalls Siegel's interest in the writings of Jacques Derrida. On the other hand, Anderson was trained in political science but not in the positivist orientation. His essay, "The Idea of Power in the Javanese Culture," drew heavily from the hermeneutic tradition, and in turn inspired Ileto to write Pasyon and Revolution.

Further illuminating Ileto's framework is his tendency to quote from Foucault, Said, and Barthes in his works. This, however, should not be interpreted as an expression of mere philosophical discipleship. On the contrary, it further expresses Ileto's interest in the ruptures of truthclaims rather than its defense, a position he shares with those thinkers. Ileto admits that his references to the works of Critical Theorists were not intended as claims of being "an expert of" this "mode of understanding" ("Scholarship, Society, and Politics" 121). Thus, to call Ileto "Foucaldian" or "Barthian" misses the point-which is Ileto's interest in promoting local knowledge and avoiding superimposed totalizations that do not come from Filipinos themselves. Moreover, a further analysis reveals deeper reasons for Ileto's criticism of strict positivist methods in the social sciences, particularly history and political science. Ileto's "more original" intention, closer to "Filipino interest," is showing how these positivist methods do not help the historian or political scientist "make sense of local conditions" (121).

\section{ILETO AND THE SEARCH FOR A FILIPINO PHILOSOPHY}

Demeterio has asserted that doing philosophy in the Philippines: (1.) must be a reflection and questioning on, and of, Philippine reality; (2.) the search for answers must creatively use any philosophical, cultural, or sociological paradigm; and (3.) it must go back to tradition which will supply future philosophical endeavors with paradigms and methodologies ("Thought and Socio-politics"). I mention these points to emphasize that Ileto's contribution to Filipino philosophy lies not in terms of systematized thinking but rather in the quality of his discourse and the impact it has had on Filipino thought. This contribution has not been examined, which returns us to the objective of this paper. 
From Ileto's scholarship, encapsulated in the presentation above, we can see that Filipino philosophy is an ongoing project. If Demeterio's claim-that the political crises experienced by the country has traumatized people's way of thinking-is true, then there is all the more a need for Filipinos to re-examine their situation. This local knowledge requires not only the translation of books written in the West to Filipino and the teaching of these books locally. What is further needed is for those teaching and doing philosophy to convince Filipinos that they don't need other people to think for them in politics, religion, law, and the rest of the areas of knowledge.

Thus we may add that Ileto's relevance to philosophizing in the Philippines is his challenge that discourse must be at the service of our own context. From this, we can say of philosophy what he said of historiography: it must be used for the "resurrection of suppressed knowledges" ("Scholarship, Society, and Politics" 121). This is further supported by his statement in a personal interview: "Filipino discourse must enable or allow Filipinos to come into terms with themselves." This insight explains the importance of a continual discussion on Filipino philosophy.

At a time when those doing philosophy in the Philippines are under pressure to match global standards, the temptation is to generate and publish ideas that are either aligned with Western discourse or relevant to the pragmatic needs of mankind. This writer is reminded of the difficulty encountered by the philosophy faculty of a local university, who struggled to relate Immanuel Kant to the university's research agenda of food security, poverty alleviation, and environmental preservation in their locality. The demand to publish or perish, coupled with the bias that Philippine publications are sub-standard, needs some serious rethinking. This reminds me of Edward Said's assertion in Culture and Imperialism:

Domination and inequities of power and wealth are perennial facts of human society. But in today's global setting they are also impenetrable as having something to do with imperialism, its history, its new forms. The nations of contemporary Asia, Latin America, and Africa are politically independent but in many ways they are dominated and dependent as they were when ruled directly by European powers. (19)

Seriously though, we need to ask how our ruminations about God, life and the world have an impact on who we are as a people-a people whom the world sees as a producer of overseas workers, whose education system is called substandard. If we cannot take a stand in the way we reflect about our world, society and self, how can we stand as a country and as individuals? Don't philosophers have anything to say about this? 
When Romualdo Abulad said in his legacy lecture that "I have always taken the stand that what we call Filipino philosophy is nothing but the collection of writings of our Filipino philosophers, and in that definition I exclude no one," he was right, but only and insofar as these writings do not just cite and parrot what American and European philosophers say. They have to facilitate our coming into terms with ourselves, keep us reflecting about who we are as a people, where we come from and what we may become.

What needs more emphasis, and has been forgotten in the decades of figuring out Filipino philosophy, is the necessity of showing that we as a people are capable of thinking for ourselves. After years of being described by Western scholars, there is a need to re-evaluate what others say about us. In order to do this, we need to first and foremost signal that we are capable of rational discourse. This is not to say that Filipino philosophy is cultural idiosyncrasy at best. But just because philosophy has universal characteristics and elements does not necessarily mean that how Plato or Frege think is how Filipinos should also think.

Ileto took the effort of interrogating, even resisting, "essentialized definitions" of the Philippines and the Filipinos, almost all of which come from western philosophy and the social sciences. Isn't this what philosophers are supposed to do? Isn't this what philosophers in the Philippines should do? Isn't this what Filipino philosophy should be all about? After decades of debate about Filipino philosophy, should we still ask if one exists?

\section{WORKS CITED}

Abulad, Romualdo. "Immanuel Kant and Postmodernism: Constructing Roots for a Filipino Philosophy." Philosophical Association of the Philippines. 26 Oct. 2012. Legacy Lecture.

-_-. "Pilosopiyang Pinoy: Uso pa ba? (The Relevance of Filipino Philosophy in Social Renewal)." College Seminary, Archdiocese of Capiz. Nov. 2011. Guest Lecture.

Agpalo, Remigio. Adventures in Political Science. Quezon City: U of the Philippines P, 1996. Print.

--- Ferdinand E. Marcos: A Hero in History. Manila: Marcos Presidential Center Inc., 2007. Print.

---. The Political Elite and the People. Manila: U of the Philippines College of Public Administration, 1972. Print.

Azurin, Arnold. "Orientalism? Privileged Vistas Most Probably." Philippine Political Science Journal. 23.46 (2002): 139-50. Print.

Co, Afredo. "Bakit Pinoy Bakit?" Across the Philosophical Silk Road: A Festschrift in Honor of Alfredo P. Co. Manila: U of Santo Tomas P, 2009. 12-15. Print. 
Rhoderick John Abellanosa, "Local Discourse, Identity and the Search for a Filipino Philosophy"

--- "Doing Philosophy in the Philippines: Fifty Years Ago, Fifty Years from Now." Across the Philosophical Silk Road: A Festschrift in Honor of Alfredo P. Co 49-62.

Contreras, Antonio. "Beyond the State: 'Postmodernizing' Political Science in the Philippines." Philippine Political Science Journal. 23.46 (2002): 49-82. Print.

De La Salle University Department of Philosophy. Readings in Filipino Philosophy. Manila: De La Salle U, 1990. Print.

Demeterio, F.P.A. "Re-reading Emerita Quito's Thoughts Concerning the Underdevelopment of Filipino Philosophy." F.P.A. Demeterio's Philosophy and Cultural Theory Page, Oct. 1998. Web. 2 Jun. 11.

---. "Thought and Socio-Politics: An Account of the Late Twentieth Century Filipino Philosophy.” F.P.A. Demeterio's Philosophy and Cultural Theory Page, Apr. 2002. Web. 30 Jun. 2011.

Dussel, Enrique. "Alterity and Modernity." Trans. J. Terry. Postcolonialism and Political Theory. Ed. Nalini Persram. Plymouth: Lexington, 2007. 3-35. Print.

Goh, Beng-Lan, ed. Decentring and Diversifying Southeast Asian Studies: Perspectives from the Region. Singapore: Institute of Southeast Asian Studies, 2011. Print.

Gripaldo, Rolando M. An Update, 1998-2002 on Filipino Philosophy: A Critical Bibliography. Unpublished work. College of Liberal Arts, De La Salle U, Manila, 2004. Print.

---. Filipino Philosophy: A Critical Bibliography, 1774-1997. $2^{\text {nd }}$ ed. Manila: De La Salle UP, 2000. Print.

---. Filipino Philosophy, Traditional Approach. Manila: De La Salle UP, 2000. Print.

Guerrero, Milagros. "Understanding Philippine Revolutionary Mentality." Philippine Studies. 29 (1981): 240-56. Print.

Ileto, Reynaldo. "Critical Issues in 'Understanding Philippine Revolutionary Mentality'." Philippine Studies. 30.1 (1982): 92-119. Print.

---. Critical Questions on Nationalism: A Historian's View. Manila: De La Salle UP, 1986. Print.

---. Filipinos and their Revolution: Event, Discourse and Historiography. Quezon City: Ateneo de Manila UP, 1998. Print.

---. Personal interview. 4 Jul. 2011.

---. Knowing America's Colony: A Hundred Years from the Philippine War. Honolulu: Center for Philippine Studies, U of Hawai'i at Manoa, 1999. Print.

--_. "On Sidel's Response and Bossism in the Philippines." Philippine Political Science Journal. 23.46 (2002): 151-74. Print.

--- "Outlines of Nonlinear Emplotment of Philippine History." The Politics of Culture in the Shadow of Capital. Eds. Lisa Lowe and David Lloyd. Durham and London: Duke UP, 1997. Print.

---. Pasyon and Revolution: Popular Movements in the Philippines, 1840-1910. Quezon City: Ateneo de Manila UP, 1979. Print.

--- "Philippine Wars and the Politics of Memory." Positions: East Asia Cultures Critique. 13.1 (2005): 215-35. Print. 
Asian Perspectives in the Arts and Humanities 3.1 (2013): 35-59

---. "Scholarship, Society, and Politics in Three Worlds: Reflections of a Filipino Sojourner, 1965-95." Decentring and Diversifying Southeast Asian Studies. Goh 10628.

Karnow, Stanley. In Our Image: America's Empire in the Philippines. New York: Random House, 1989. Print.

Lande, Carl. "Political Clientelism, Developmentalism and Postcolonial Theory: A Reply to Ileto." Philippine Political Science Journal. 23.46 (2002): 119-28. Print.

Lemert, Charles and Garth Gillan. Michel Foucault, Social Theory and Transgression. New York: Columbia UP, 1982. Print.

May, Glenn. Inventing a Hero: The Posthumous Re-Creation of Andres Bonifacio. Quezon City: New Day, 1997. Print.

Mojares, Resil. Brains of the Nation: Pedro Paterno, T.H. Pardo de Tavera, Isabelo de los Reyes, and the Production of Modern Knowledge. Quezon: Ateneo de Manila UP, 2006. Print.

Park, Jin Y. Comparative Political Theory and Cross-Cultural Philosophy. Lanham: Rowman, 2009. Print.

Quito, Emerita. The State of Philosophy in the Philippines. Manila: De La Salle UP, 1983. Print.

--_. "The State of Philosophy in the Philippines." Readings in Filipino Philosophy. Manila: De La Salle UP, 1983. Print.

Quito, Emerita, Romualdo Abulad, Florentino Timbreza, and Herminia Reyes. Ensayklopidiya ng Pilosopiya. Manila: De La Salle UP, 1993. Print.

Said, Edward. Culture and Imperialism. New York: Vintage, 1994. Print.

---. Orientalism. New York: Vintage, 1979. Print.

Sidel, John. "Response to Ileto: Or, Why I am not an Orientalist." Philippine Political Science Journal. 23.46 (2002): 129-38. Print.

Rhoderick John Abellanosa is currently at the last stage of his doctoral program in Philosophy at the University of San Carlos, Cebu City (Philippines). He has Master's degrees in Philosophy and Political Science from the same university. In 2011, he was awarded a Graduate Research Fellowship by the Asia Research Institute of the National University of Singapore. His research interests include political theory, state and church relations and Filipino political thought. 